\title{
Type and Potential Sources of Polycyclic Aromatic Hydrocarbons (PAHs) in Coastal Area of Tarakan City, North Borneo, Indonesia
}

\author{
Ratno Achyani ${ }^{1 *}$, Dietriech G Bengen ${ }^{2}$, Tri Prartono ${ }^{2}$, Etty Riani ${ }^{3}$, Abdullah Hisam bin Omar $^{4}$ \\ ${ }^{1}$ Departement of Aquatic Resources Management, Faculty of Fishery And Marine Sciences, \\ Borneo of Tarakan University \\ Jl. Amal Lama Nomor 1, Tarakan, Kalimantan Utara 77123 Indonesia \\ 2Departement of Marine Sciences, Faculty of Fishery and Marine Sciences, , IPB University \\ ${ }^{3}$ Departement of Aquatic Resources Management, Faculty of Fishery and Marine Sciences, IPB University \\ Jl. Rasamala, Kampus IPB Darmaga Bogor 16680 Indonesia \\ ${ }^{4}$ Faculty of Built Environment and Surveying, Universiti Teknologi Malaysia \\ Sultan Ibrahim Chancellery Building, Jalan Iman, 81310 Skudai, Johor, Malaysia \\ Email: ratno_achyani@yahoo.com
}

\begin{abstract}
PAHs are mutagenic and carcinogenic agents that influence the coastal water of Tarakan City. This study aims to determine the concentration, type, and distribution of PAHs in waters and sediments of rivers, seawater, and brackish ponds, and their potential sources. Fourteen samples of water and sediment from selected stations obtained 14 types of PAHs priority (USEPA). Analysis using GC-MS Type Thermo Trace 1310 single quadrupole Mass Spectrometer, using Coulum melting silica column (coulumn fused silica) DB5 MS with a length of $30 \mathrm{~m}$, a diameter of $0.32 \mathrm{~mm}$ inline. The concentration in sediments at river locations ranges from 0.72-352.84, between 1.23606.74 in the sea, and brackish ponds 0.08-2858.88 ng.g-1. On the waters ranged from 42.46-160.25 $\mu \mathrm{g} . \mathrm{L}^{-1}$, in the sea 7.95-167.55 $\mu \mathrm{g} . \mathrm{L}^{-1}$ and ponds 7.63-151.60 $\mu \mathrm{g} . \mathrm{L}^{-1}$. The concentration level in rivers and seas is small and in the ponds is small-very high. The concentration on water at the river site was observed to increase from upstream to downstream. Meanwhile in sediment was higher in the upstream decreased towards the middle of river and increased in downstream/estuary area. The concentration in the Tarakan coastal environment signifies the potential hazards to the environment. Components Nap, Fla, Pyr, Chr, and BaP are types that are often identified. Furthermore, two, four and five rings of PAHs were shown to dominate in water and sediment, with the major rings present in both river and brackish pond. The PAHs were both petrogenic and pyrolytic sources from land base sources that were possibly derived from the Pamusian river.
\end{abstract}

Keywords: PAHs, coastal area, river, brackish pond, distribution

\section{Introduction}

The city of Tarakan, North Kalimantan, Indonesia, is located in coastal areas and acts as a provider of natural resources, life support, and comfort services. $38.2 \%$ of the city is an island, while $61.8 \%$ consists of the ocean with \pm 20 rivers (BPS 2011). Coastal town of Tarakan is densely residential areas of economic activity, traffic area large vessels, public ports and stevedoring. Along the coast there is also a stream that empties into the sea. Increased anthropogenic activities along the river such as oil and gas exploration activity, residential, industrial, workshop and others. These activities have the potential to influence the environmental conditions of coastal waters of the city, including through the entry of harmful pollutants such as polycyclic aromatic hydrocarbons (PAHs).

PAHs are mutagenic and carcinogenic, and their concentration in certain levels in water and sediments may be toxic to benthic and pelagic marine organisms (Arias et al., 2009). In the environment, concentrations above $1-50 \mu \mathrm{\mu g} \mathrm{L}^{-1}$ may cause sublethal responses in some sensitive organisms (Neff, 1979). According to Achyani et al. (2015), Tarakan City sea has been polluted by PAHs with a total concentration of 6-248 $\mu \mathrm{g} . \mathrm{L}^{-1}$ in water, and sediments 7-69 $\mu \mathrm{g} . \mathrm{L}^{-1}$ and also accumulates in the body of marine life that fish nomei (Horpodon nehereus) $27-422 \mathrm{ng}^{-1}$. This contaminant is thought to have accumulated in another fish resource, namely milkfish (Chanos chanos) on traditional ponds. These fish, PAHs accumulate through aquaculture water that comes from exposed sea water. PAHs in the aquatic environment will enter the milkfish body through their gills and food (moss, algae and klekap). The presence and concentration in certain levels on seawater and sediments can be toxic to benthic and pelagic marine organisms (Arias et al., 2009). Their presence is believed to affect fish resources, especially traditional milkfish aquaculture ponds, 
which are currently experiencing a decline in production. This condition was accorded to be an impact of $\mathrm{PAH}$ input into the pond through rivers and seawater, then used as a source of aquaculture water in the pond. Furthermore, there is presently no information on the existence of PAH in brackish pond cultivation areas.

The rivers in Tarakan may be a source of PAH, as there are lots of anthropogenic activities, including in the Pamusian river. However, there is no information on the existence of $\mathrm{PAH}$ in these rivers. The currents are assumed to transport PAH from the sources directly into the water or through the land, and then carried by rain and rivers into the sea. Furthermore, the existence, distribution, and risks in the coastal ecosystem of Tarakan city have not been ascertained. The aim of this study was to determine the type, concentration, source, and risk of PAH presence in rivers, seas, and brackish ponds in the coastal environment of Tarakan City.

\section{Materials and Methods}

Field studies were carried out in rivers, sea ponds, and brackish pond milkfish in the city of Tarakan, North Kalimantan, Indonesia. See Figure 1.
Sampling was performed on the Pamusian River, which has many community and economic activities along its routes, namely Kampung Satu (Kp 1), Kramat (Krm), and Mamburungan (Mbr). The sampling locations at sea included Tanjung Pasir (TjP), Mamburungan (Mbr), Tengkayu port (Sdf), Tibi (Tbi), Juata (Jta), Andulung (Adl) and Amal (Aml). Furthermore, in the traditional milkfish ponds, sampling locations were Mbr, Karang Anyar Pantai (Krp), Jta, and Adl.

Surface water samples were obtained using a van dorn water sampler with a capacity of two liters. They were placed into a dark bottle previously rinsed with methanol and hexane. Furthermore, sediment samples from the bottom of the water were obtained at a depth of $3 \mathrm{~cm}$ using Ekman grab. The samples were then taken to the laboratory, placed in an icebox, and stored in the freezer.

The sample extraction was carried out according to the procedure of Achyani et al. (2015). PAH type analysis used GC-MS Thermo Trace 1310 Single Quadrupole Mass Spectrometer, GC-MS Coulum using a DB5 MS fused silica column with a length of $30 \mathrm{~m}$ and a diameter of $0.32 \mathrm{~mm}$ in line. The GC program temperature was set at $70^{\circ} \mathrm{C}$ and raised to $7^{\circ} \mathrm{C} \cdot \mathrm{min}^{-1}$ to $250^{\circ} \mathrm{C}$, and then $1^{\circ} \mathrm{C} \cdot \mathrm{min}^{-1}$ to $270^{\circ} \mathrm{C}$.

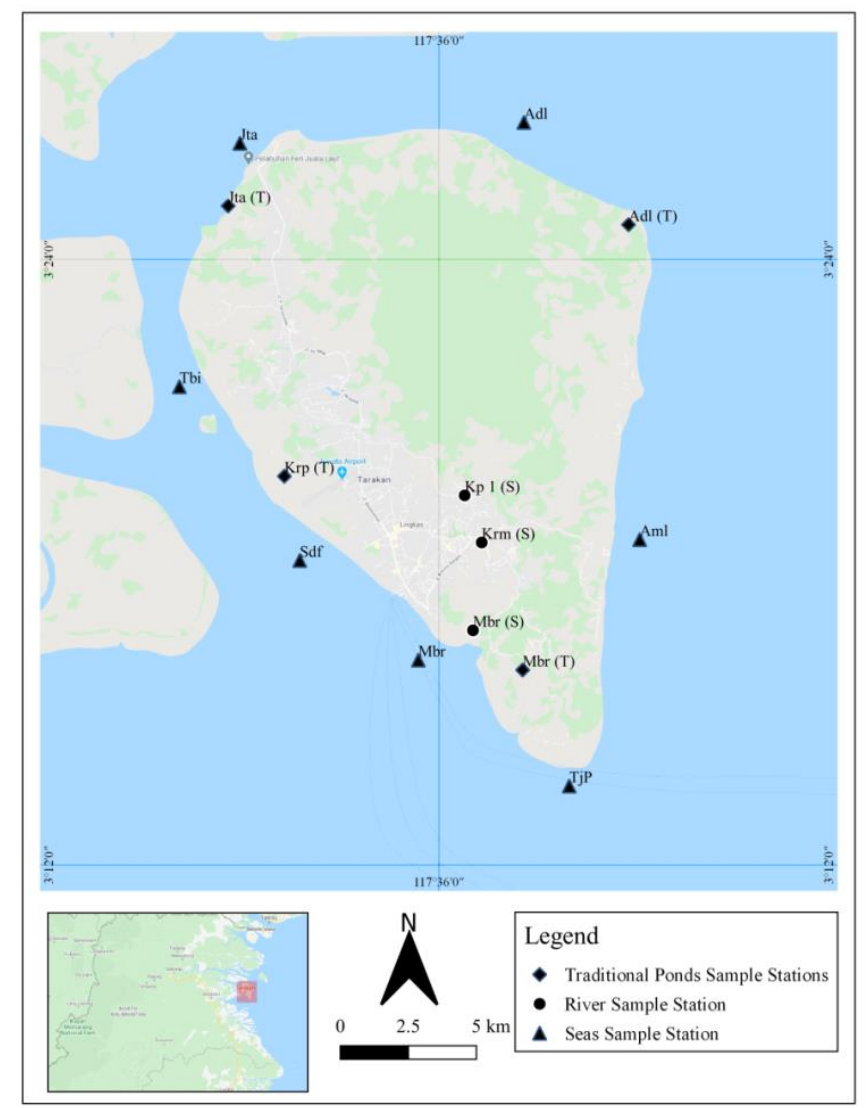

Figure 1 Sampling locations in the sea, rivers and Brackish ponds, Tarakan City, North Borneo, Indonesia 
The 14 priority PAHs according to the USEPA in this study were LMW (low molecular weight) naphthalene (Nap), acenaphthene (Ace), acenaphthylene (Acy), fluorene (Flu), phenanthrene (Phe), and HMW (high molecular weight), fluoranthene (Fla), pyrene (Pyr), benzo (a) anthracene $(\mathrm{BaA})$, chrysene (Chr), benzo (b) fluoranthene $(\mathrm{BbF})$, benzo ( $k$ ) fluoranthene (BkF), benzo (a) pyrene (Chr) $\mathrm{BaP})$, Dibenzo $(\mathrm{a}, \mathrm{h})$ anthracene $(\mathrm{DbA})$, and Benzo (g, $\mathrm{h}$, i) perylene (BgP). To ensure the quality of the analysis, the method utilized a blank sample, spike samples, duplicate samples and internal standard $\mathrm{p}$ -

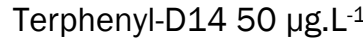

Table 1 shows the ratio of $\mathrm{PAH}$ pollutant sources in the sea and river waters which include LMW/HMW, Fla/(Fla+Pyr), $\mathrm{BaA} /(\mathrm{BaA}+\mathrm{Chr})$, and $\mathrm{BaP} /(\mathrm{BaP}+\mathrm{Chr})$. Table 2 shows the assessment of $\mathrm{PAH}$ concentration levels in sediments in accordance with Baumard et al. (1999). The risk quotients (RQ) method used to determine the ecological risk of PAHs presence (Cao et al., 2010) is shown in Table 3.

\section{Result and Discussion}

Fourteen types of PAHs were observed in all stations (Table 4.). Components Nap, Fla, Pyr, Chr, and $\mathrm{BaP}$ are types that are often identified in water and sediment. Furthermore, in rivers and ponds, all 14 types were found, while at sea locations, PAHs were more common in TjP station, Mbr, and Sdf. Their presence in all sample locations signified that the coastal areas of Tarakan City have been contaminated with PAHs.

Table 5 and 6 show $\sum$ PAH concentrations in water and sediment. In rivers, the concentration on water ranged from 42.46-160.25 $\mu \mathrm{g} . \mathrm{L}^{-1}$, in the sea

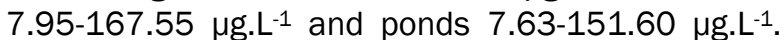
The concentration of $\sum \mathrm{PAH}$ in sediment at river sites ranged between 232.95-1007.63 $\mathrm{ng} \mathrm{g}^{-1} \mathrm{dw}$, in the sea 72.11-874.82 ng.g-1 dw, and in ponds 68.98$6718.22 \mathrm{ng}^{-1} \mathrm{~g}^{-1} \mathrm{dw}$. The concentration on water at the river site was observed to increase from upstream to downstream. Meanwhile, the concentration in sediment was higher in the upstream (Kp 1), decreased towards the middle of the river (Krm) and increased in the downstream/estuary area (Mbr). This reflected the high PAHs input from terrestrial activities. This is also found in the Luan River estuary, Hai River estuary, and Zhangweixin River estuary (Yan et al., 2016), Teluk Jakarta (Ahmad, 2012), Mahakam river (Hadibarata et al., 2019) where the concentration value at rivers and estuaries / bays are affected by differences in organic pollutant input from the activities above them such as commercial, residential and industrial activities. High concentrations in the sea on sediment, which are close to river estuaries such as Mbr, Sdf and TjP as well as at pond locations, namely Mbr and Krp, indicate that the estuary is an area that accumulates PAHs.

Table 1. Parent PAHs ratio of the source estimator

\begin{tabular}{|c|c|c|c|c|c|c|}
\hline Rasio & Pyrolitic & Petrogenic & Petroleum & $\begin{array}{l}\text { Fosil Fuel /Combustion/ } \\
\text { Vehicle Exhaust/mixed }\end{array}$ & $\begin{array}{c}\text { Grass, Wood, } \\
\text { Coal Combustion }\end{array}$ & Refferences \\
\hline LMW/HMW & $<0.1$ & $>0.1$ & - & 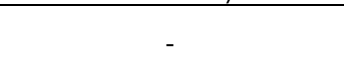 & (1) & $\begin{array}{l}\text { Kanzari et al. } \\
\text { (2014) }\end{array}$ \\
\hline $\mathrm{Fla} /(\mathrm{Fla}+\mathrm{Pyr})$ & & & $<0.4$ & $0.4-0.5$ & $>0.5$ & \multirow{2}{*}{$\begin{array}{c}\text { Yunker et al. } \\
(2015)\end{array}$} \\
\hline $\mathrm{BaA} /(\mathrm{BaA}+\mathrm{Chr})$ & & & $<0.2$ & $0.2-0.35$ & $>0.35$ & \\
\hline $\mathrm{BaP} /(\mathrm{BaP}+\mathrm{Chr})$ & & & $<0.2$ & 0.4-0.6 & $>0.6$ & Ahmad (2013) \\
\hline
\end{tabular}

Table 2. Concentration levels PAHs in sediments (ng.g-1) (Baumard et al., 1999)

\begin{tabular}{ccccc}
\hline $\begin{array}{c}\text { Concentration } \\
\text { LPAHs }\end{array}$ & Low & Medium & High & Very high \\
& $0-100$ & $100-1000$ & $1000-5000$ & $>5000$ \\
\hline
\end{tabular}

Table 3. Ecological risk classification of individuals and total PAHs (Cao et al., 2010)

\begin{tabular}{|c|c|c|c|c|c|c|}
\hline & \multicolumn{2}{|c|}{ Individual PAHs } & \multicolumn{3}{|c|}{$\sum \mathrm{PAHs}$} & \\
\hline $\mathrm{RQ}$ (NCs) & RQ(MPCs) & & Score & RQ $\sum$ PAHs(NCs) & \multicolumn{2}{|c|}{ RQ $\sum$ PAHs (MPCs) } \\
\hline 0 & - & Risk free & 1 & 0 & - & Risk free \\
\hline$\geq 1$ & $<1$ & Moderate risk & 2 & $\geq 1 ;<800$ & 0 & Low risk \\
\hline \multirow[t]{3}{*}{-} & $\geq 1$ & High risk & 3 & $\geq 800$ & 0 & Moderate risk-1 \\
\hline & & & & $<800$ & $\geq 1$ & Moderate risk-2 \\
\hline & & & & $\geq 800$ & $\geq 1$ & High risk \\
\hline
\end{tabular}


ILMU KELAUTAN: Indonesian Journal of Marine Sciences March 2021 Vol 26(1):27-36

Table 4. Types of PAHs identified in water and sediment at all observation sites
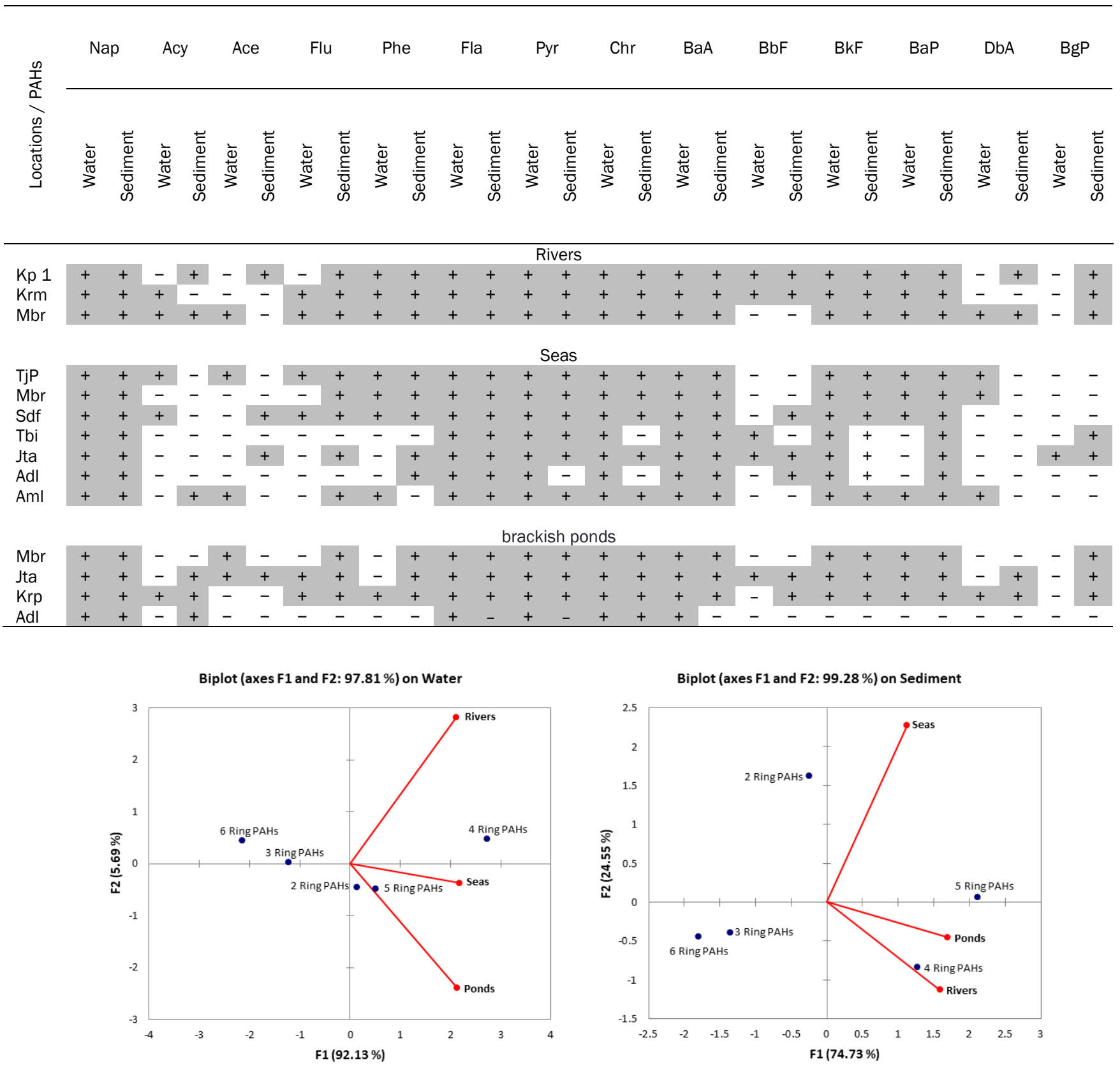

Figure 2. Distribution of PAHs based on the amount of carbon chain at any location on the water and sediment

The concentration of PAHs in water in Tarakan City river is still smaller than that of Dalian river (W Hong et al., 2016), Luan, Hai, and Zhangweixin rivers (Yan et al., 2016) (Table 7.). In seawater, there were lower levels than in Pearl River estuary (Niu et al., 2018), Liaodong Bay (Zhang et al., 2016), Coastal area of Dalian (Hong et al., 2016), and Coastal Alexandria (Ahmed et al., 2017). Furthermore, $\sum$ PAHs concentration in sediments, in general, is very high (Table 8.). When compared to other locations, the concentration in river sediments in Tarakan City is still smaller than Huveaune River (Kanzari et al., 2014). The sediments in marine areas are also lower than in the Liaodong Bay location (Zhang et al., 2016), Daya Bay (Sun et al., 2016), Osaka Bay (Miki et al., 2014), Dalian coastal area (Hong et al., 2016), and the Mediterranean coast (Barakat et al., 2011) (Table 9.).

The PCA analysis shown in Figure 2 signifies that the spatial distribution of PAHs in water was dominated by cyclic 4 and cyclic $2(90.78 \%)$ and in sediments, dominated by cyclic chains 4 and 5 
(87.09\%). PAHs in water, on ponds and sea, dominate in different types, although they are in the same area. For example, the location for pond samples and seawater showed a difference. In seawater, cyclic carbon 4 is dominant, but in ponds, the concentration of cyclic carbon two is dominant, though the water source for cultivation in the pond comes from the same area. Meanwhile, the distribution of PAHs in sediment showed that cyclic chain 4 dominates in ponds and rivers.

Both total and individual PAHs found in water and sediments (Table 1.) are derived from petrogenic and pyrogenic sources, i.e combustion/waste vehicles, petroleum, grass burning, wood burning, and coal (Figure 3.). This shows that anthropogenic activities significantly influence the presence of PAHs in Tarakan, including the activities of residents (Zeng et al., 2018). In general, PAHs also originate from petrogenic (fossil fuels; oil and coal) and pyrogenic (incomplete combustion; urban dust, oil, and wood burning) sources. The difference between them can be estimated by the number of cyclics (for example, petrogenics are associated with 2-3 cyclic carbons, while pyrogenics are associated with 4-6 cyclic carbons).

The presence of Nap, Flu, Phe, and Chr compounds (thermodynamically more stable) as petrogenic sources, may come from atmospheric deposition, spills and waste of crude oil and their derivatives (Fernandez et al., 2015; Santos et al., 2018). Meanwhile, the presence of Fla and Pyr are usually the most abundant compounds as a pyrogenic feature (He et al., 2014). Pyrolytic and petrogenic PAHs are the dominant sources found in other sites, including the coastal aquatic environment (Table 10). The difference in the presence of PAHs in water and sediments such as Acy, Ace, and BbF were due to several factors, such as lipophilic chemical properties which have low solubility and are easily absorbed into sediment (Achyani et al., 2015). The existence of PAHs in Pamusian River show that this river is one of sources of entry into the coastal waters of Tarakan City.

Table 5. Concentrations of PAHs in marine waters, ponds and rivers Tarakan City (ng.L-1)

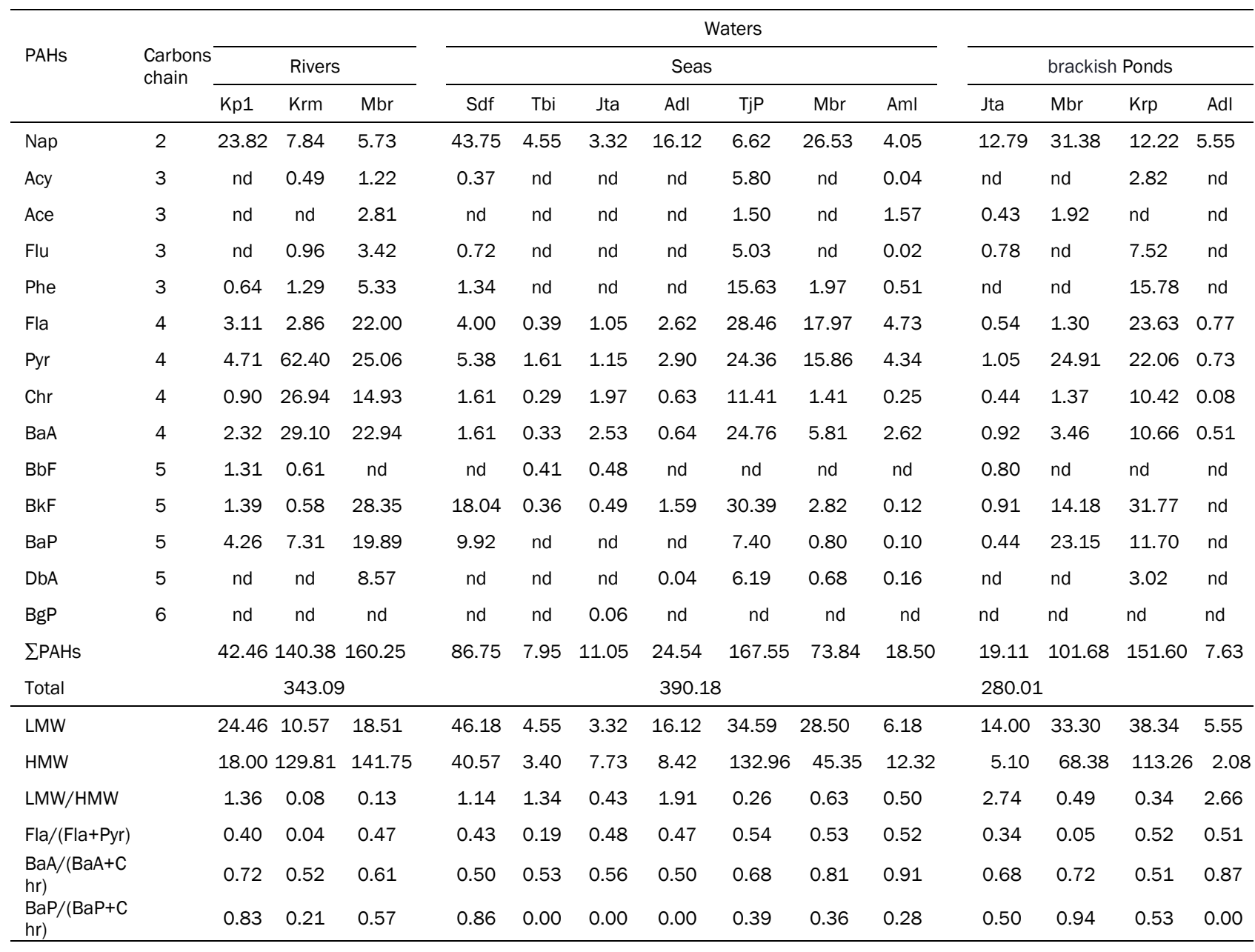

Note : nd = not detection 
ILMU KELAUTAN: Indonesian Journal of Marine Sciences March 2021 Vol 26(1):27-36

Table 6. Concentrations of PAHs in the sediments of the sea, ponds and rivers in Tarakan City (ng.g-1)

\begin{tabular}{|c|c|c|c|c|c|c|c|c|c|c|c|c|c|c|c|}
\hline \multirow{3}{*}{ PAHs } & \multirow{3}{*}{$\begin{array}{l}\text { Carbons } \\
\text { chain }\end{array}$} & & & & \multicolumn{7}{|c|}{ Sediments } & & & & \\
\hline & & \multicolumn{3}{|c|}{ Rivers } & \multicolumn{7}{|c|}{ Seas } & \multicolumn{4}{|c|}{ brackish Ponds } \\
\hline & & Kp1 & $\mathrm{Krm}$ & Mbr & Jta & Aml & Adl & Mbr & Sdf & Tbi & TjP & Jta & Krp & Adl & Mbr \\
\hline Nap & 2 & 31.80 & 3.78 & 9.06 & 262.71 & 43.20 & 24.22 & 523.56 & 39.89 & 17.80 & 606.74 & 10.08 & 352.66 & \multicolumn{2}{|c|}{$24.751,020.12$} \\
\hline Acy & 3 & 1.46 & nd & 3.51 & nd & 4.95 & nd & nd & nd & nd & nd & 5.75 & 0.06 & 2.65 & nd \\
\hline Ace & 3 & 1.00 & nd & nd & 2.82 & nd & nd & nd & 1.23 & nd & 0.02 & 1.46 & nd & nd & nd \\
\hline Flu & 3 & 2.30 & 2.26 & 20.20 & 8.25 & 18.90 & nd & 19.02 & 1.79 & nd & 11.43 & 6.13 & 177.42 & nd & 244.60 \\
\hline Phe & 3 & 7.70 & 8.33 & 20.56 & 8.33 & $\mathrm{ttd}$ & 2.52 & 1.90 & 2.46 & nd & 49.30 & 16.35 & 143.73 & nd & 298.48 \\
\hline Fla & 4 & 40.56 & 28.92 & 43.04 & 26.12 & 37.86 & 0.94 & 71.60 & 19.21 & 1.13 & 17.63 & 73.09 & 601.91 & nd & 348.48 \\
\hline \multirow{2}{*}{$\begin{array}{l}\text { Pyr } \\
\text { Chr }\end{array}$} & 4 & 352.84 & 32.54 & 45.32 & 22.16 & 31.32 & nd & 73.10 & 21.25 & 1.82 & 21.07 & 229.92 & 785.07 & nd & 530.39 \\
\hline & 4 & 46.31 & 0.94 & 30.42 & 40.44 & 17.05 & nd & 24.40 & 2.16 & nd & 24.30 & 116.50 & 304.01 & 41.59 & 568.62 \\
\hline $\mathrm{BaA}$ & 4 & 48.42 & 59.77 & 30.63 & 44.40 & 17.39 & 5.32 & 57.90 & 15.24 & 4.16 & 24.93 & 35.65 & 303.27 & nd & 551.06 \\
\hline $\mathrm{BbF}$ & 5 & 62.59 & 35.46 & nd & 131.32 & nd & 3.04 & nd & 73.65 & nd & nd & 7.17 & 66.39 & nd & ntd \\
\hline $\mathrm{BkF}$ & 5 & 198.47 & 44.02 & 93.83 & 154.47 & 89.96 & 3.80 & 337.53 & 50.55 & 7.25 & 90.43 & 12.112 & $2,179.66$ & nd & $1,105.64$ \\
\hline $\mathrm{BaP}$ & 5 & 199.21 & 16.22 & 46.26 & 64.39 & 18.22 & 19.67 & 147.28 & 20.52 & 39.69 & 28.95 & 143.79 & $1,767.20$ & nd & 781.25 \\
\hline $\mathrm{DbA}$ & 5 & 11.60 & nd & 0.86 & 0.00 & nd & nd & nd & nd & nd & nd & 2.64 & 32.73 & nd & nd \\
\hline BgP & 6 & 3.39 & 0.72 & 1.06 & 0.59 & nd & nd & nd & nd & 0.25 & nd & 32.35 & 4.10 & nd & 15.35 \\
\hline $\begin{array}{l}\sum_{\mathrm{HS}} \mathrm{PA} \\
\mathrm{H}\end{array}$ & & 1008 & 233 & 345 & 766 & 279 & 60 & 1256 & 248 & 72 & 875 & 693 & 6718 & 69 & 5464 \\
\hline Total & & & 1585 & & & & & 3556 & & & & & 1294 & 44 & \\
\hline $\begin{array}{l}\text { LM } \\
\text { W }\end{array}$ & & 44.26 & 14.37 & 53.34 & 282.12 & 67.05 & 26.74 & 544.47 & 45.36 & 17.80 & 667.50 & 39.78 & 673.87 & 27.40 & $1,563.20$ \\
\hline $\begin{array}{l}\mathrm{HM} \\
\mathrm{W}\end{array}$ & & 963.37 & 218.58 & 291.42 & 483.90 & 211.80 & 32.76 & 711.81 & 202.58 & 54.31 & 207.32 & 653.23 & $6,044.34$ & 41.59 & $3,900.79$ \\
\hline LMW/I & HMW & 0.05 & 0.07 & 0.18 & 0.58 & 0.32 & 0.82 & 0.76 & 0.22 & 0.33 & 3.22 & 0.06 & 0.11 & 0.66 & 0.40 \\
\hline $\mathrm{Fla} /(\mathrm{Fl}$ & $a+P y r)$ & 0.10 & 0.47 & 0.49 & 0.54 & 0.55 & 1.00 & 0.49 & 0.47 & 0.38 & 0.46 & 0.24 & 0.43 & 0.00 & 0.40 \\
\hline $\mathrm{BaA} /(\mathrm{E}$ & $\mathrm{BaA}+\mathrm{Chr})$ & 0.51 & 0.98 & 0.50 & 0.52 & 0.50 & 1.00 & 0.70 & 0.88 & 1.00 & 0.51 & 0.23 & 0.50 & 0.00 & 0.49 \\
\hline $\mathrm{BaP} /(\mathrm{E}$ & $\mathrm{BaP}+\mathrm{Chr})$ & 0.81 & 0.95 & 0.60 & 0.61 & 0.52 & 1.00 & 0.86 & 0.90 & 1.00 & 0.54 & 0.55 & 0.85 & 0.00 & 0.58 \\
\hline
\end{tabular}

Note $:$ nd $=$ not detection

Table 7. Comparison of PAHs concentrations in seawater, rivers and ponds in the coastal area of Tarakan City and other sites worldwide (ng.L-1)

\begin{tabular}{|c|c|c|c|c|c|}
\hline Research sites & $\sum \mathrm{PAHs}$ & River & Sea & Ponds & Reference \\
\hline $\begin{array}{c}\text { Coastal environment of Tarakan } \\
\text { City, Indonesia }\end{array}$ & 14 & $1.71-92.48$ & $0.89-104.95$ & $\begin{array}{l}0.08- \\
31.77\end{array}$ & This Study \\
\hline Pearl River estuary (China) & 16 & & $12.70-160.15$ & & Niu et al. (2018) \\
\hline Northern Liaodong Bay, China & 16 & & $145.96-896.58$ & & $\begin{array}{l}\text { D. Zhang et al. } \\
\text { (2016) }\end{array}$ \\
\hline Luan River estuary, China & 14 & 231.12-3663.52 & & & Yan et al. (2016) \\
\hline Hai River estuary, China & 14 & 287.49-3796.97 & & & \\
\hline $\begin{array}{c}\text { Zhangweixin River estuary, } \\
\text { China }\end{array}$ & 14 & $305.67-7596.56$ & & & \\
\hline $\begin{array}{c}\text { Coastal area of Dalian, North } \\
\text { China }\end{array}$ & 46 & $65.0-1130$ & $136-621$ & & Hong et al. (2016) \\
\hline Pesisir Alexandria, Mesir & 16 & & $8971-1254756$ & & Ahmed et al. (2017) \\
\hline
\end{tabular}



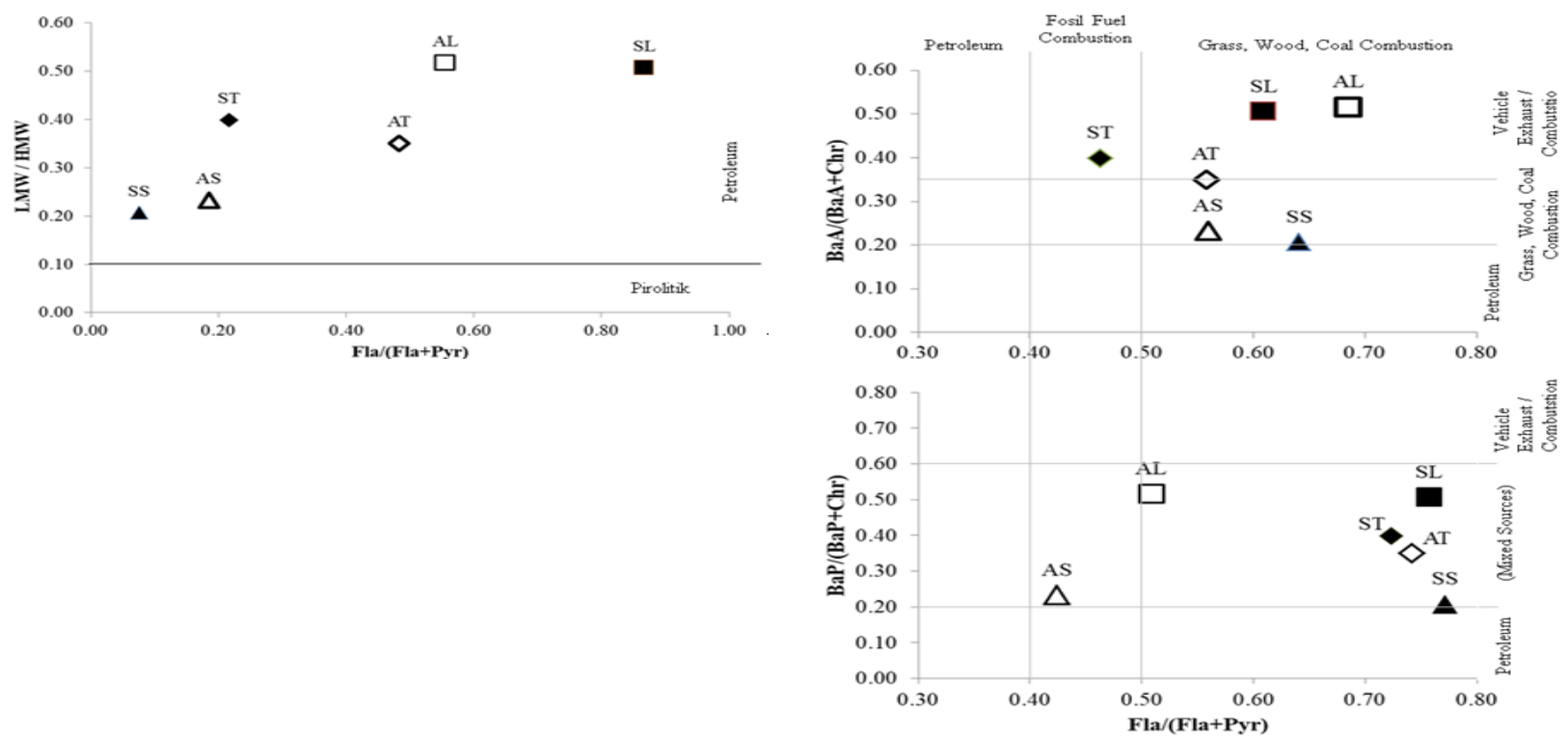

Figure 3. Estimation ratio of PAHs sources in water and sediments in rivers, seas and ponds based on a) LMW / HMW ratio, b) $\mathrm{Fla} \mathrm{/} \mathrm{(Fla} \mathrm{+} \mathrm{Pyr)} \mathrm{to} \mathrm{BaA} \mathrm{/} \mathrm{(BaA} \mathrm{+} \mathrm{Chr),} \mathrm{c)} \mathrm{Fla} \mathrm{/} \mathrm{(Fla} \mathrm{+} \mathrm{Pyr)} \mathrm{against} \mathrm{BaP} \mathrm{(Bap} \mathrm{+} \mathrm{Chr).} \mathrm{(river} \mathrm{water} \mathrm{(US);} \mathrm{river} \mathrm{sediment} \mathrm{(SS);}$ sea water (AL); sea sediment (SL); ponds water (AT); ponds sediment (ST))

Table 8. Rankings of $\Sigma$ PAHs concentration levels in sediment at each station ( $\left.\mu g \cdot g^{-1}\right)$

\begin{tabular}{ccccc}
\hline & Low & Medium & High & Very high \\
Site/ $\Sigma$ PAHs & $1-100$ & $100-1000$ & $1000-5000$ & $>5000$ \\
\hline Rivers & & & $1,585.34$ & \\
Seas & & $3,555.53$ & $12,944.19$ \\
Ponds & & & \\
\hline
\end{tabular}

Table 9. Concentrations of PAHs in the sediment of rivers, seas, and coastal ponds in Tarakan City and other locations worldwide (ng.g-1)

\begin{tabular}{|c|c|c|c|c|c|}
\hline Research sites & $\sum$ PAHs & Rivers & Seas & Ponds & Reference \\
\hline $\begin{array}{l}\text { Coastal environment of Tarakan City, } \\
\text { Indonesia }\end{array}$ & 14 & $1.00-430.69$ & $0.85-1.518$ & $\begin{array}{c}90.48- \\
8811.73\end{array}$ & This study \\
\hline Pearl River estuary (China) & 16 & & 2.82-112.32 & & Niu et al. (2018) \\
\hline Northern Liaodong Bay, China & 16 & & 146.0-896.6 & & $\begin{array}{l}\text { D. Zhang et al. } \\
\text { (2016) }\end{array}$ \\
\hline The Daya Bay, South China. & 16 & & $340-710$ & & Sun et al. (2016) \\
\hline Coastal area of Dalian, North China & 46 & & $172-4700$ & & Hong et al. (2016) \\
\hline The Luan River Estuary, China & 16 & & $5.1-545.1$ & & $\begin{array}{l}\text { A. Zhang et al. } \\
\text { (2016) }\end{array}$ \\
\hline $\begin{array}{c}\text { Industrialized urban river (Huveaune), } \\
\text { France }\end{array}$ & 16 & $572-4235$ & & & $\begin{array}{l}\text { Kanzari et al. } \\
\quad(2014)\end{array}$ \\
\hline Osaka Bay, Japan & 16 & & $6.40-7800$ & & Miki et al. (2014) \\
\hline $\begin{array}{l}\text { The Mediterranean coastal environment } \\
\text { of Egypt }\end{array}$ & 39 & & $13.5-22,600$ & & $\begin{array}{c}\text { Barakat et al. } \\
(2011)\end{array}$ \\
\hline
\end{tabular}

The areas along the coastal city of Tarakan have dense economic activity, densely populated settlements, shipping traffic, and ports, with many rivers flowing into the sea, especially in the west. In addition, the increase in anthropogenic activities such as oil and gas exploration activities, settlements, 
ILMU KELAUTAN: Indonesian Journal of Marine Sciences March 2021 Vol 26(1):27-36

Table 10 Sources of PAHs in Coastal Waters of Tarakan compared with sources in several cities worldwide

\begin{tabular}{|c|c|c|c|c|c|}
\hline Location & $\begin{array}{l}\text { Waters } \\
(\text { ng L-1) }\end{array}$ & $\begin{array}{l}\text { Sediment } \\
\left(\mu g g^{-1}\right)\end{array}$ & Sources & $\mathrm{n}$ & Refferences \\
\hline Teluk Jakarta, Indonesia & & 257-1511 & Pirolitik dan Petrogenik & $\begin{array}{l}1 \\
5\end{array}$ & $\begin{array}{l}\text { Rinawati et al. } \\
\quad(2012)\end{array}$ \\
\hline Coast of Alexandria, Mesir & $\begin{array}{c}\text { 8971- } \\
1254756\end{array}$ & & Pirolitik dan Petrogenik & $\begin{array}{l}1 \\
6\end{array}$ & $\begin{array}{l}\text { Ahmed et al. } \\
\quad(2017)\end{array}$ \\
\hline $\begin{array}{c}\text { Coastal region Dalian, Cina } \\
\text { Utara }\end{array}$ & $65.0-1130$ & 71.1-1090 & - & $\begin{array}{l}4 \\
6\end{array}$ & Hong et al. (2016) \\
\hline Turki Canal, Turki & & 120- 2912 & Pirolitik dan Petrogenik & $\begin{array}{l}1 \\
6\end{array}$ & $\begin{array}{l}\text { Balcioglu et al. } \\
\qquad(2018)\end{array}$ \\
\hline Mahakam river, Indonesia. & & $\begin{array}{c}54.7- \\
2256.15\end{array}$ & $\begin{array}{l}\text { HMW : combustion, } \\
\text { LMW : coal combustion and } \\
\text { biomass burning }\end{array}$ & $\begin{array}{l}1 \\
6\end{array}$ & $\begin{array}{l}\text { Hadibarata et al. } \\
\text { (2019) }\end{array}$ \\
\hline $\begin{array}{c}\text { Coastal region Tarakan City, } \\
\text { Indonesia }\end{array}$ & 1356.4 & 19670 & Pirolitik dan Petrogenik & $\begin{array}{l}1 \\
4\end{array}$ & This study \\
\hline
\end{tabular}

Table 11. Potential risks from the presence of individuals and $\Sigma$ PAHs in waters and sediment to ecosystems in rivers, oceans and ponds

\begin{tabular}{|c|c|c|c|c|c|c|c|c|c|c|c|c|}
\hline \multirow{3}{*}{ PAHs } & \multicolumn{6}{|c|}{ Waters } & \multicolumn{6}{|c|}{ Sediment } \\
\hline & \multicolumn{2}{|l|}{ Rivers } & \multicolumn{2}{|c|}{ Seas } & \multicolumn{2}{|l|}{ Ponds } & \multicolumn{2}{|l|}{ Rivers } & \multicolumn{2}{|c|}{ Seas } & \multicolumn{2}{|l|}{ Ponds } \\
\hline & (NCs) & (MPCs) & (NCs) & (MPCs) & (NCs) & (MPCs) & (NCs) & (MPCs) & (NCs) & (MPCs) & (NCs) & (MPCs) \\
\hline Nap & 1.04 & 0.01 & 1.25 & 0.01 & 1.29 & 0.01 & 10.63 & 0.11 & 154.91 & 1.55 & 272.36 & 2.72 \\
\hline Acy & 0.82 & 0.01 & 1.27 & 0.01 & 1.01 & 0.01 & 1.38 & 0.01 & 0.59 & 0.01 & 1.94 & 0.02 \\
\hline Ace & 1.34 & 0.01 & 0.63 & 0.01 & 0.84 & 0.01 & 0.28 & $\mathrm{ttd}$ & 0.48 & $\mathrm{ttd}$ & 0.3 & $\mathrm{ttd}$ \\
\hline Flu & 2.08 & 0.02 & 1.18 & 0.01 & 2.96 & 0.03 & 6.88 & 0.07 & 7.07 & 0.07 & 100.72 & 1.01 \\
\hline Phe & 0.81 & 0.01 & 0.93 & 0.01 & 1.32 & 0.01 & 2.39 & 0.02 & 1.81 & 0.02 & 24.67 & 0.25 \\
\hline Fla & 3.11 & 0.03 & 2.82 & 0.03 & 2.19 & 0.02 & 1.44 & 0.01 & 0.96 & 0.01 & 11.64 & 0.12 \\
\hline Pyr & 43.89 & 0.44 & 11.35 & 0.11 & 17.41 & 0.17 & 119.64 & 1.2 & 20.33 & 0.2 & 372.92 & 3.73 \\
\hline Chr & 4.19 & 0.04 & 0.74 & 0.01 & 0.91 & 0.01 & 0.24 & $\mathrm{ttd}$ & 0.14 & $\mathrm{ttd}$ & 2.66 & 0.03 \\
\hline $\mathrm{BaA}$ & 181.18 & 1.81 & 54.72 & 0.55 & 38.86 & 0.39 & 12.85 & 0.13 & 6.72 & 0.07 & 68.37 & 0.68 \\
\hline $\mathrm{BbF}$ & 100.93 & 1.01 & 76.75 & 0.77 & 116.88 & 1.17 & 9.08 & 0.09 & 8.25 & 0.08 & 6.55 & 0.07 \\
\hline BkF & 25.27 & 0.25 & 19.22 & 0.19 & 29.29 & 0.29 & 4.67 & 0.05 & 4.37 & 0.04 & 41.42 & 0.41 \\
\hline $\mathrm{BaP}$ & 20.98 & 0.21 & 5.21 & 0.05 & 17.65 & 0.18 & 3.23 & 0.03 & 1.79 & 0.02 & 30.03 & 0.3 \\
\hline $\mathrm{DbA}$ & 7.14 & 0.07 & 2.53 & 0.03 & 1.89 & 0.02 & 0.15 & $\mathrm{ttd}$ & $\mathrm{ttd}$ & $\mathrm{ttd}$ & 0.42 & $\mathrm{ttd}$ \\
\hline BgP & $\mathrm{ttd}$ & $\mathrm{ttd}$ & 0.03 & $\mathrm{ttd}$ & $\mathrm{ttd}$ & ttd & 0.02 & $\mathrm{ttd}$ & $\mathrm{ttd}$ & $\mathrm{ttd}$ & 0.18 & 0.02 \\
\hline$\sum$ PAHs & 392.78 & 3.93 & 178.61 & 1.79 & 232.48 & 2.32 & 172.89 & 1.73 & 207.43 & 2.07 & 934.18 & 9.36 \\
\hline
\end{tabular}

wood processing industries, workshops and other activities along with river flows, also influence the city's marine environment. Anthropogenic activities such as waste or oil spills containing PAHs, industrial waste, urban runoff which are discharged directly into the aquatic environment, emissions from the atmosphere such as petroleum refineries, industrial incinerators, and burning agricultural land also pose a contributing factor (Neff, 1979). The presence and concentration of PAHs in aquatic ecosystems often correlate with industrial discharge, spills, atmospheric deposition, and fuel combustion (Yan et al., 2016). From the literature study, land-based activities constitute PAHs sources in the coastal waters of Tarakan City.

The concentration of individual PAHs, as well as the risk of their existence in the coastal ecosystem of Tarakan City, is moderate. However, the concentration of Pyr, BbF, and $\mathrm{BaA}$ compounds which are $\mathrm{HMW}$, are believed to be high risk. HMW components are highly carcinogenic, and therefore dangerous, especially for aquatic biota such as milkfish and Kappah shellfish. Based on the concentration of $\mathrm{PPAHs}$, the existential risk is Moderate (risk-2) (Table 11.). Therefore, the presence of PAHs in the coastal environment of Tarakan is considered potentially dangerous, and subsequent action is needed to reduce their impact on the environment.

\section{Conclusion}

PAHs have been observed to pollute the coastal town of Tarakan. This is demonstrated by the 
discovery of 14 compounds in the Tarakan coastal environment. The sediment concentration was higher than in water, and the sources are pyrogenic, petrogenic and land-based. Furthermore, their presence in the river signifies that the river is a source of input. The existence of PAHs in coastal ecosystems of Tarakan City constitutes a potential danger to the environment, especially aquatic biota.

\section{Acknowledgement}

Special thanks to KEMENRISTEKDIKTI Doctoral Disertation Research Grant 2017.

\section{References}

Achyani, R., Prartono, T. \& Riani, E. 2015. Polycyclic Aromatic Hydrocarbons (PAHs) in seawater , marine sedimen and their accumulation in the Bombay-duck, Harpadon nehereus (Hamilton, 1822) of Tarakan waters. J. Iktiologi Indo., 15(3): 267-282.

Ahmad, F. 2012. Kandungan Senyawa Polisiklik Aromatik Hidrokarbon (PAH) di Teluk Jakarta (Polycyclic Aromatic Compounds Hydrocarbons (PAH) Content in Jakarta Bay). IImu Kelautan: Indonesian Journal of Marine Science, 17(4): 199-208. doi: 10.14710/ik.ijms.17.4. 199208

Ahmed, O. E., Mahmoud, S. A. \& El Nady, M. M. 2017. Organic sources in the Egyptian seawater around Alexandria coastal area as integrated from polycyclic aromatic hydrocarbons (PAHs). Egyp. J. Petrol. 26(3): 819-826 doi: 10.1016/j.ejpe.2016.10. 016

Albuquerque, M., Coutinho, M. \& Borrego, C. 2016. Science of the Total Environment Long-term monitoring and seasonal analysis of polycyclic aromatic hydrocarbons ( PAHs ) measured over a decade in the ambient air of Porto, Portugal. Sci. Total Environ., 543: 439-448. doi: 10.1016/j.scitotenv.2015.11.064

Arias, A.H., Spetter, C.V., Freije, R.H. \& Marcovecchio, J.E. 2009. Polycyclic Aromatic Hydrocarbons In Water, Mussels (Brachidontes sp., Tagelus sp.) and Fish (Odontesthes sp.) from Bahiia Blanca Estuary, Argentina. Est. Coast Shelf Sci., 85: 67-81. doi: 10.1016/j.ecss.20 09.06.008

Balcioglu, E.B., Gonulal, O., Ozan, S., Aksu, A. \& Öztürk, B. 2018. Comparison and origins of polycyclic aromatic hydrocarbons ( PAHs ) in the entrance and the exit of the Turkish Straits System (TSS ). Mar. Poll. Bull. 136: 33-37. doi:

\subsection{6/j.marpolbul.2018.08.066}

Barakat, A.O., Mostafa, A., Wade, T.L., Sweet, S.T. \& EI, N.B. 2011. Distribution and characteristics of PAHs in sediments from the Mediterranean coastal environment of Egypt. Mar. Poll. Bull., 62(9): 1969-1978. doi: 10.1016/j.marpol bul.2011.06.024

Baumard, P., Budzinski, H., Garrigues, P. \& Narbonne, J.F. 1999. Polycyclic aromatic hydrocarbon ( $\mathrm{PAH}$ ) burden of mussels (Mytilus sp.) in different marine environments in relation with sediment $\mathrm{PAH}$ contamination, and bioavailability. Mar. Environ. Res. 47:415-439

BPS. 2011. Kota Tarakan Dalam Angka 2011. BPS (Badan Pusat Statistik) Kota Tarakan

Cao, Z., Liu, J., Luan, Y., Li, Y., Ma, M., Xu, J. \& Han, S. 2010. Distribution and ecosystem risk assessment of polycyclic aromatic hydrocarbons in the Luan River, China. Ecotoxicol., 19(5): 827-837. doi: 10.1007/ s10 646-010-0464-5

Dunbar, J.C., Lin, C., Vergucht, I., Wong, J. \& Durant, J.L. 2001. Estimating The Contributions Of Mobile Sources Of PAH To Urban Air Using RealTime PAH Monitoring. Sci. Total Environ., 279: $1-19$

Fernandez, B.P., Viñas, L., Franco, M.Á. \& Bargiela, J. 2015. PAHs in the Ría de Arousa (NW Spain): A consideration of PAHs sources and abundance. Mar. Poll. Bull., 95(1): 155-165. doi: 10.1016/ j.marpolbul.2015.04.028

Hadibarata, T., Sya, A. \& Ghfar, A.A. 2019. Abundance and distribution of polycyclic aromatic hydrocarbons (PAHs) in sediments of the Mahakam River. Mar. Poll. Bull., 149:110650. doi: 10.1016/j.marpolbul.2019. 110650

He, J., Fan, S., Meng, Q., Sun, Y., Zhang, J. \& Zu, F. 2014. Polycyclic aromatic hydrocarbons (PAHs) associated with fine particulate matters in Nanjing, China: Distributions, sources and meteorological influences. Atmosph. Environ., 89: 207-215. doi: 10.1016/j.atmosenv.2014. 02.042

Hong, W. J., Jia, H., Li, Y. F., Sun, Y., Liu, X. \& Wang, L. 2016. Polycyclic aromatic hydrocarbons (PAHs) and alkylated PAHs in the coastal seawater, surface sediment and oyster from Dalian, Northeast China. Ecotoxicol. Environ. Safe., 128: 11-20. doi: 10.1016/j.ecoenv. 2016.02. 003 
Hong, W., Jia, H., Li, Y., Sun, Y., Liu, X. \& Wang, L. 2016. Ecotoxicology and Environmental Safety Polycyclic aromatic hydrocarbons (PAHs ) and alkylated PAHs in the coastal seawater, surface sediment and oyster from Dalian, Northeast. Ecotoxicol. Environ. Safe., 128: 11-20. doi: 10.1016/j.ecoenv.2016.02.003

Kanzari, F., Syakti, A.D., Asia, L., Malleret, L., Piram, A., Mille, G. \& Doumenq, P. 2014. Distributions and sources of persistent organic pollutants (aliphatic hydrocarbons, PAHs, PCBs and pesticides) in surface sediments of an industrialized urban river (Huveaune), France. Sci. Total Environ., 478: 141-151. doi: 10.1016/j.scitotenv.2014.01.065

Keshavarzifard, M., Zakaria, M.P., Shau Hwai, T., Mohamat Yusuff, F.F., Mustafa, S., Vaezzadeh, V., Magam, S.M., Masood, N., Alkhadher, S.A.A. \& Abootalebi-Jahromi, F. 2014. Baseline distributions and sources of Polycyclic Aromatic Hydrocarbons (PAHs) in the surface sediments from the Prai and Malacca Rivers, Peninsular Malaysia. Mar. Poll. Bull., 88(1-2): 366-372. doi: 10.1016/j.marpolbul.2014.08. 014

Miki, S., Uno, S., Ito, K., Koyama, J. \& Tanaka, H. 2014. Distributions of polycyclic aromatic hydrocarbons and alkylated polycyclic aromatic hydrocarbons in Osaka Bay, Japan. Mar. Poll. Bull., 85(2): 558-565. doi: 10.1016/j.marpol bul.2014.04.004

Neff, J.M. 1979. Polycyclic aromatic hydrocarbons in the aquatic environment: sources, fates, and biological effects. Applied Science Publishers,.

Niu, L., Cai, H., Van Gelder, P. H. A. J. M., Luo, P., Liu, F. \& Yang, Q. 2018. Dynamics of polycyclic aromatic hydrocarbons (PAHs) in water column of Pearl River estuary (China): Seasonal pattern, environmental fate and source implication. App. Geochem., 90: 39-49. doi: 10.1016/j.apgeo chem.2017.12.014

Rinawati, Koike, T., Koike, H., Kurumisawa, R., Ito, M., Sakurai, S., Togo, A., Saha, M., Arifin, Z. \& Takada, H. 2012. Distribution, source identification, and historical trends of organic micropollutants in coastal sediment in Jakarta Bay, Indonesia. J. Hazar. Mat., 217: 208-216 doi: 10.1016/ j.jhazmat.2012.03.023

Santos, E., Souza, M.R., Junior, A.R.V., Soares, L.S., Frena, M. \& Alexandre, M.R. 2018. Polycyclic aromatic hydrocarbons (PAH) in superficial water from a tropical estuarine system: Distribution, seasonal variations, sources and ecological risk assessment. Mar. Poll. Bull., 127: 352-358. doi: 10.1016/j.marpolbul.20 17.12.014

Sun, R., Lin, Q., Ke, C., Du, F., Gu, Y. \& Cao, K. 2016. Polycyclic aromatic hydrocarbons in surface sediments and marine organisms from the Daya Bay, South China. Mar. Poll. Bull. 103(12): 325-332. doi: 10.1016/j.marpolbul.2016. 01.009

Van der Oost, R., Beyer, J. \& Vermeulen, N.P.E. 2003. Fish bioaccumulation and biomarkers in environmental risk assessment: A review. 13(2): 57-149. In Environ. Toxicol. Pharmacol., doi: 10.1016/S1382-6689(02)00126-6

Yan, J., Liu, J., Shi, X., You, X. \& Cao, Z. 2016. Polycyclic aromatic hydrocarbons (PAHs) in water from three estuaries of China: Distribution, seasonal variations and ecological risk assessment. Mar. Poll. Bull., 109(1): 471479. doi: 10.1016/j.marpolbul.2016.05.025

Yunker, M.B., Macdonald, R.W., Ross, P.S., Johannessen, S.C. \& Dangerfield, N. 2015. Alkane and $\mathrm{PAH}$ provenance and potential bioavailability in coastal marine sediments subject to a gradient of anthropogenic sources in British Columbia, Canada. Organic Geochemistry, 89-90: 80-116. doi: 10.1016 /j.orggeochem.2015.10.002

Zeng, Q., Jeppesen, E., Gu, X., Mao, Z. \& Chen, H. 2018. Distribution, fate and risk assessment of PAHs in water and sediments from an aquaculture- and shipping-impacted subtropical lake, China. Chemosphere, 201: 612-620. doi: 10.1016/j.chemosphere.2018. 03.031

Zhang, A., Zhao, S., Wang, L., Yang, X., Zhao, Q., Fan, J. \& Yuan, X. 2016. Polycyclic aromatic hydrocarbons (PAHs) in seawater and sediments from the northern Liaodong Bay, China. Mar. Poll. Bull., 113(1-2): 592-599. doi: 10.1016/j.marpolbul.2016.09.005

Zhang, D., Liu, J., Jiang, X., Cao, K., Yin, P. \& Zhang, X. 2016. Distribution, sources and ecological risk assessment of PAHs in surface sediments from the Luan River Estuary, China. Mar. Poll. Bull., 102(1): 223-229. doi: 10.1016/j.mar polbul. 2015.10.043 